\title{
FEMINISM IN PATRIARCHAL SOCIETY REFLECTED IN THE MAIN CHARACTER OF PEREMPUAN BERKALUNG SORBAN MOVIE
}

\author{
*Farida Hannum Siagian \\ **Dr. I Wy.Dirgeyasa T. M.Hum. \\ **IndraHartoyo, S.Pd., M.Hum.
}

\begin{abstract}
Siagian, Farida Hannum. 212322015. Feminism in a Patriarchal Society Reflected in The Main Character of PerempuanBerkalungSorban Movie. A Thesis.English Literature.Faculty of Languages and Arts.State University of Medan. 2018.

This study is aimed to analyze what the feminism varieties and how is the feminism in patriarchal reflected by main character Annisa in Perempuan Berkalung Sorban movie. This study is conducted with the descriptive qualitative method. The source of the data of the analysis is Perempuan Berkalung Sorban movie and the data are linguistic feature that are format as sentence by the main character. The data were collected by the documentary technique and the instrument is documentary sheets. The study results that (1) The main character reflected the feminism varieties. Based on the Feminist Thought book there are three varieties of feminism. Liberal feminism, Radical feminism and Socialist Marxists feminism. The main character reflected the three kinds of feminism such as Liberal Feminism, Radical feminism, Socialist Marxist Feminism. The main character Annisa is reflected most dominant appeared Radical feminism. Annisa is powerful and rebellious women. She wants to get the equal with the man without any discrimination gender. (2) The feminism in patriarchal society in reflected is Annisa to represent the women movement to against all of objection toward woman. The each utterances of Annisa represent she is against all forms of women discrimination in private patriarchy and public patriarchy. The research focuses on the analysis of feminism in patriarchal society in the main character can be interpreted through Annisa as a main character and sentences of the movie and it is found of the main character reflected the feminism in a patriarchal society.
\end{abstract}

Keywords:feminism, varieties, patriarchal, main character, movie.

*Graduate Status

**Lecturer Status 


\section{INTRODUCTION}

\section{Background of the study}

Feminism is a movement to fight for the rights of women to get the equal rights without any discrimination. Feminism refers to a series of campaigns for reforms on issues such as reproductive rights, domestic violence, maternity leave, equal pay, women's suffrage, sexual harassment, and sexual violence.

Feminism fights for two things that have not been obtained by women, First, it is equality with men to decide what is good for them in many aspects. Second, the position of women in the society is lower than men, even thisis regarded as "the second sex".

According to Walby (1990:24) "Patriarchy as a system of social structures and practices in which men dominate, oppress and exploit women." and she also divides patriarchal into a two types, such as private patriarchy and publicpatriarchy. An example of the problems of feminism in a patriarchal society can be described from literary works such as novels and movie through the main character.

This study is supposed to enrich the knowledge about feminism the image of women in the literary work is better studied by using feminist approach. It can be analyzed through the approach because the literary work is related to a woman as one of the characters in the movie. Perempuan Berkalung Sorban movie, is the object of the research of the main character, played by Revalina S Temat, she shows the image of woman feminism in patriarchal a society. Based on the reason 
above, this study is proposed to analyze the feminism in patriarchal society reflected in the main character, Annisa in Perempuan Berakalung Sorban movie. This study will reveal how itis reflected the feminism in the main character.

\section{REVIEW OF LITERATURE}

\section{Feminism}

Feminism is a concept that moves women to demanding gender equality or equality in society. Charles (2013:4) as the etymology is derived from the Latin the word feminist from Latin "femina", which means to have a woman hood than added to the word "Isms" which can mean the concept.Bowers (2004) starts the feminism definition by stating that feminism is known as the women movement and woman view based on the literary works. Feminism is a political attitude and movement that call for

the status, rights and desire of women to be taken into consideration in all aspects of life.

Hooks (2002) also believes that feminism is a movement to end sexism, sexist exploitation and oppression. She believes that is definition gives a broad understanding about feminism as it does not imply that men are the enemy of women but all the sexist thinking and action is the problem. This study will focus on the movement of women in which men and women are the inequality into the equality.

\section{Feminism Varieties}

Based on theFeminist Thought book by Rosemarie Thongthere are three varieties of feminism: 


\section{a. Liberal Feminism}

Liberal feminism is one of theory that can be used to describe gender inequality. Liberal feminist have thought of that the men and women have the same capacity.

In the economic women are considered an incompetent in terms of work, because of gender equality has not been achieved men believe that women cannot take the risk of being responsible and are autonomously decision making it makes women were given the lower salaries.

In the family when a woman married she is cannot to be a career women because their just follow the husband to take care of children as the housewife.

\section{b. Radical Feminism}

Appears a reaction of sexism in the radical feminism movement in the West years 1960s.Marilyn French In her book Beyond Power, French suggests that the traditional nature of women is better than the traditional male nature of. The stratification man over woman in turn is lead to the class stratification.

The explanation of the reason women are the oppressed can be seen from the statement Alison Jaggar and Paula Rothenberg in the Feminist Thought book by Rosemarie Thong. (Tong, 2009:49) The claim that women's oppression as women is morefundamental than other forms of human oppression is difficult tounload. According to Alison Jaggar and Paula Rothenberg, it can be interpreted to mean one or more of five things:

1. That women were, historically, the first oppressed group 
2. That women's oppression is most widespread, existing in virtually every known society.

3. That women's oppression is the hardest form of oppression to eradicate and cannot be removed by other social changes such as abolition of class society.

4. That women oppression causes the most suffering to its victims, qualitatively as well as quantitatively, although the suffering may often go unrecognized because of the sexist prejudices of both the oppressors and the victims.

5. That women's oppression provides a conceptual model for understanding all other forms of oppression

\section{c. Socialist and Marxist Feminism}

Classical Marxist feminist work within the conceptual terrain laid out by Marx. Engels, Lenin and other nineteenth-century thinkers.In Marxist economic theory, Marxist feminists believe that women's work shape the thinking of women and therefore form also natural of women traits. They also believe that capitalism is an exploitative system of power relations (employer has greater power, making the workers to work harder) and the exchange relationship (working for pay, the relationship is traded).

The example of Marxist Socialist is a divorced woman by men bourgeois.This woman is a member of the bourgeoisie just because of marriage, a 
result she is an honorary member of the middle class. But beyond the marriage relationship, this woman should be earning their living itself and take on place in the working class where she became a member of a lifetime.

\section{Patriarchy}

The word 'patriarchy' 'literallymeansthe rule of the father or the 'patriacrh', and originally it was used to describe a specific type of 'male dominated family'. According to Walby "Patriarchy as a system of social structures and practices in which men dominate, oppress and exploit women."“In this system women's labour power, women's reproduction, women and other economic resources are under patriarchal control" (Walby 1990: 20). Walby divided patriarchy into two. "Two distinct forms of private patriarchy and public patriarchy".(Walby 1990:24).

The women in Perempuan Berkalung Sorban movie show the imbalance of power in a patriarchal society. This gender inequality of power by gave birth make the discriminate for women. The discrimination is indicated for of men to make the assumption that women are inferior position.

\section{Character}

Wellek and warren (1949:15) state that a character in a literary work differs from a historical figure or a figure in real life. On other hand, Bennet and Royle (2004:60) state that character are the life of literature: they are the objects of our 
curiosity and fascination, affection and dislike, admiration and condemnation. Main Character

Klarer (2004:10) states that main character is depicted in more detail and with greater care, thereby moving beyond the classical epic whose main character function primarily as the embodiment of abstract heroic ideals. Pope (2005:133) establishes two categories of character. A major character is an important figure at the center of the story's action of theme. The major character is sometimes called a protagonist whose conflict with an antagonist may spark the story's conflict. And minor character is a character is to illuminate the major character.

\section{Movie}

According to Kridaklasana (1984:32) movie is an audio-visual media that can be seen by many people. It is a type of visual communication which used moving pictures and sound to tell stories or inform.

\section{Synopsis of Perempuan Berkalung Sorban Movie}

This movie is about the life journey of Anissa (Revalina S. Temat), as the main character who is smart, brave, optimistic and independent. Anissa grew up in the conservative Islamic tradition of Kyai family who manages small Pondok Pesantren Salafiah of Al-Huda in East Java, Indonesia. In the conditions and the conservative traditions the only science must be based on the Qur'an, the Hadith and Sunnah, while the modern books are considered as deviated doctrine. 
The Pesantren Salafiah of Al-Huda teaches how to be a woman who must be submissive to men, until Anissa assumed that Islam only defends men and puts women in weak and inequality position. But her father ignore her protests. Only Khudori (Oka Antara), Anissa's uncle of the mother who always accompanies Anissa, and entertains Annisa and service another 'world' for her. Anissa secretly falls in love with him.

But love is not unrequited because Khudori realizes he is not close with Kyai Hanan (Joshua Pandelaki), Anissa's father. In fact Anissa is married to Samsudin (Reza Rahadian), a son of Kyai Salaf pesantren in East Java. Even though Anissa refuses, but the wedding is held. In reality, Samsudin behaves rude and oppresses Annisa and he gets married again to Kalsum (Francine Roosenda). Annisa's expectation to become an independent Muslim woman is immediately destroyed. In her work, Anissa meets with Khudori and they fall in love with each other. The movie tells the journey of Anissa's love story and her struggle for a position to defend the rights of Muslim women with many barriers in her Pesantren and conservative family situation. 


\section{RESEARCH METHOD AND FINDINGS}

\section{Method}

This study was conducted by using descriptive qualitative method. Ary (2000: 425) states that the qualitative inquirer deals with data in the form of words, rather than numbers and statistics.

The data source of this study is "Perempuan Berkalung Sorban" movie. It was produced in 2009 based on the problem of social life which a Feminsim by Hannung Bramantyo and released by Kharisma Starvision Plus. The data which are reflected to the feminism varieties in patriarchal reflections on the main character of this study are the linguistic features that are formed in sentence.

The data were collected by the documentary technique. In other words, the data were simply made into written text as the document. The utterances were used as the data which reflected the feminism in patriarchal society in the main character.

In order to collect the data, the documentary sheets were used as the instrument collect data.

after the data were collected, they were analyzed by using some procedures as follows:

1. Identifying the utterances which are related to the main character in the movie and explain the feminism varieties in patriarchal analysis 
2. Reducing the data which are not relevant to feminism varieties in patriarchal society representation of the main characters

3. Classifying utterances as the data which represent feminism varieties in patriarchal society of Annisa as main character

4. Analyzing and interpreting the feminism in patriarchal reflection of Annisa

5. Concluding the feminism in patriarchal reflection of Annisa in patriarchal society

\section{Findings}

After analyzing the data, the findings of this research were presented as follows:

1. There were three feminism varieties reflected on the women main character in the Perempuan Berkalung Sorban movie, (a) Liberal feminism, (b) Radical feminism and (c) Socialist Marxist feminism. From the 14 selected the utterances founded that radical feminism is more dominant than others. It means Radical feminism reflection of Annisa in accordance with feminism in patriarchal. Radical feminism is more aim to the movement of feminism which refers to patriarchal culture. In represented a liberal feminism Annisa is fighting for ability like a men. Annisa is struggle for do sports like men. In represent a radical feminism when Annisa wants to eliminate for oppression from her husband. She is often got the violence from her husband. In representing a socialist marxist feminism Annisa strives for divorce from her 
husband Syamsudin because he treats her badly and she wants to change the mindset of a gender difference that discriminates women.

2. The feminism in patriarchal society as reflected in women main character is that she struggles in both the private patriarchy and public patriarchy. Private patriarchy is households and public patriarchy is the scope of the society. In the reflected the feminism in private patriarchy is Annisa cannot go to college because the status is a wife of Syamsudin. She wants to freedom for her husband's bad behavior. In public patriarchy is Annisa loves horse riding but her father forbids her because she is a woman. Annisa is reflected feminism in patriarchal society is aimed to fighting for equality, justice and the dignity of women and men.

\section{CONCLUSION AND SUGGESTION}

\section{Conclusion}

There are some main points that can be considered as the conclusions of the study, they are:

1. The feminism varieties represented in the main character of Perempuan Berkalung Sorban movie there are Liberal feminism, Radical feminism and Socialist Marxist feminism. From the 14 selected utterances found the radical feminism is dominant to reflected by Annisa. Reflected in Liberal feminism Annisa is citing the ability between men and women. In radical feminism Annisa wants to ability as man. In Socialist Marxist 
Annisa reflected the feminism in the marriage as a symbol of capitalism to women

2. The feminism in a patriarchal society reflected is when Annisa make her own choices an equality as a man does, and to get her freedom. It is proved finally she got to the college and be carrier women. She successed eliminated the patriarchy that used the terms of "male power" which is domination of men over women and now Annisa can be the equality as men in take her choices and working like men without having to intimidate from the physical.

\section{Suggestions}

There are several suggestions that can be offered based on the analysis of the study, they are:

1. The students who are interested in learning feminism prespective should know about what feminism means and how it is implied in literary work in movie, based on the results of analysis as it becomes more easily learn and revealed the feminism varieties that can be found in the woman main character. In analyzing the feminism by the main character, it is suggested for they who are interested to do similar research can enrich their references.

2. The readers should be more aware of the gender problem. The feminism in a patriarchal society brought the spirit to women to fight for feminism to woman should behave and be treated in the daily lives. 


\section{REFERENCES}

Abrams, M, H. 1999. A Glossary of Literary Terms, Seventh Edition.Cornel. University. Baruch, G. K. 1972. "Maternal influences upon college women's attitudes toward women and work" Development Psychology, 6, 32-37.

Blackweel, Willey, 2008. A Companion To Modernist Literature and Culture. Simgapore.

Bennett, A, and Royle, N. 2004.An Introduction to Literature, Criticism and Theory: Edinburgh: Pearson Education Limited.

Bowers. 2004. Maggie Ann Magic(al) Realism. Routledge

Gurein. 2005. 1992. The fifth edition of A Handbook of Critical Approaches to Literature. New York. Oxford University Press.

Hook, Bell, 2000. Feminism Is Everybody: Passionate Politics. Cambridge: South End Press.

June, Hannam, 2013.Feminism. New York

Klerer, M. 2004. An Introduction to Literature Studies; Second Edition. London.

Pope, R. 2005. Creativity: Theory, History Practice. New York

Tong, Rosemarie, 2009.Feminist Thought. University of North Carolina.

Westview Press. 
